\title{
Challenges and Opportunities of Micro and Small Munifacturing Enterprises the Case of Easter Zone of Tigray
}

\author{
Desalegn Berhane Asgedom \\ Lecturer, Adigrat University, Ethiopia, Africa
}

\begin{abstract}
The study presented in this paper analyzes the challenges and opportunities of micro and small manufacturing enterprises in Easter Zone of Tigray. The study has collected relevant information from a survey of 323 entrepreneurs and interviewees from micro and small enterprises agency as sources of primary data for the study. Systematic random sampling was used to select sample respondents from the selected district towns, while purposive for interviewees from the micro and small enterprises Agency. Then the analysis was conducted using SPSS version 20 software. The result indicated that there are seldom young entrepreneurs with high school level of education. The entrepreneurs have good attitude towards the business. The entrepreneurs face financial difficulties due to high collateral requirements from the financial institutions. The plants do not have adequate machineries and modern technology. They are not good in distributing their products to their respective customers. The enterprises have good relationship with customers. Hence there is a scope for developing and expanding their business. There is an interruption in electric power supply which hinders the enterprises performance. Therefore, entrepreneurs should intend to take basic trainings and/or formal education so as to be more competent in the business world. Moreover, both entrepreneurs and government should make effort to ensure electric power supply continuously.
\end{abstract}

Keywords: Entrepreneurs, Management, Manufacturing, Marketing, Power, Tigray.

\section{Introduction}

Medium and Small scale enterprises play very important roles in the process of industrialization and sustainable economic growth. Lara and Simeon (2009:1453-1464) found that the MSE sector generates substantial employment and economic output in many countries. Especially The dynamic role of micro and small enterprises (MSEs) in developing countries has been recognized as engines through which the growth objectives of developing countries can be achieved in a planned manner. Micro and Small enterprises play significant roles in the creations of employment opportunities and generations of income for quite a large proportion of the population. In developing countries, MSEs by virtue of their size, capital investment and their capacity to generate greater employment, have demonstrated their powerful propellant effect for rapid economic growth. The MSE sector has also been instrumental in bringing about economic transition by providing goods and services, (ILO 2008:56). Their share of overall employment tends to be higher in developing countries, which are typically more focused on small-scale production.

The sector has given a conducive environment and has enabled entrepreneurs to optimally exercise their talents and to attain their personal and professional goals (MoTI, 1997:9). In all successful economies, MSEs are seen as an essential catalyst for growth, job creation and social progress. The small business sector is also seen as a tool to generate more equitable income distribution, activate competition, exploit niche markets, and enhance productivity and technical changes..

In Ethiopia, MSEs are the second largest employment generating sector next to agriculture. A National survey conducted by Central Statistics Agency (CSA) in 2007 indicates that more than 1.3 million people in the country are engaged in MSEs sector. But a large number of MSEs are unable to grow (expand in terms of employment) and remain to be survival (non-growing) type which cannot provide employment.

The study conducted by Ethiopian CSA indicates that, the contribution of small enterprises in creating job opportunities in Ethiopia is vital (FMSEDA, 2006:13). However, their contribution is very low when comparing with that of other countries. This may be due to various factors such as financial problem, maintenance financial records, inadequacy in qualified employees, inefficiency in operations and marketing, poor infrastructure and working premises. Mulu Gebreeyesus, 2009 highlights such factors hinders the performance of MSEs in Ethiopia. It seems it is more son in the case of Micro small and medium manufacturing enterprises (MSMEs).

\section{Statement of the problem}

Micro and small enterprises have been identified the world as the stepping stones for industrialization. Similarly in Ethiopia, these enterprises are known in bringing economic transition by effectively using the skill and the talent of citizens without deploying much capital and sophisticated technology.

Konjit D. (2010) has stated that:

"Micro and Small Enterprise Development Program in Ethiopia meaningfully has been given due attention by government since 2004/2005. Of course, in 1996/97 National Micro and Small Enterprise Strategy was developed by the government. However, the degree of recognition to the sector with regards to job creation and the alleviation of 


\section{International Journal of Science and Research (IJSR) \\ ISSN (Online): 2319-7064}

Index Copernicus Value (2013): 6.14 | Impact Factor (2015): 6.391

abject poverty among impoverished youth and women were not sufficient',

Depending on the respective government policies, Micro and small enterprises are defined in several countries within their different purposes and intention differently. According to the new micro and small enterprises development strategy of Ethiopia (published 2011), enterprises are classified based on size of capital and labor as follow:

Table 1: Definition of MSEs according to Ethiopian Trade and Industry Office

\begin{tabular}{|c|c|c|c|}
\hline Enterprise & Sector & Employee & Capital \\
\hline \multirow{2}{*}{$\begin{array}{c}\text { Micro- } \\
\text { enterprise }\end{array}$} & Industry & $\begin{array}{c}\text { Less than or } \\
\text { equal to five }\end{array}$ & $\begin{array}{c}\text { Less than or equal to five } \\
\text { ETB } 100,000.00 \text { or } \$ 6000.00\end{array}$ \\
\cline { 2 - 5 } & Service & $\begin{array}{c}\text { Less than or } \\
\text { equal to five }\end{array}$ & $\begin{array}{c}\text { Less than or equal to five } \\
\text { ETB 50,000.00 or } \$ 3000.00\end{array}$ \\
\hline $\begin{array}{c}\text { Small- } \\
\text { enterprise }\end{array}$ & Industry & 30-Jun & $\begin{array}{c}\text { Less than or equal to five } \\
\text { ETB } 1.500,000.00 \text { or } \\
\$ 990,000.00\end{array}$ \\
\cline { 2 - 4 } & Service & 30-Jun & $\begin{array}{c}\text { Less than or equal to five } \\
\text { ETB 500,000.00 }\end{array}$ \\
\hline
\end{tabular}

Source: Ethiopian Micro and Small Enterprises Strategy (2011)

Despite the vital role of MSEs in building a competitive private sector and contributing significantly to economic growth and job creation, SMEs are facing more challenges around the world in general and in developing countries in particular Asma Benzazoua et., al (2015).In line with this Akabueze as cited in Mekonnen et., al 2013, indicated that the inherent problems which affect long term survival and business performance of MSEs due to lack of financial resources, management experiences, poor location, poor infrastructure, low demand for products or services, corruption and shortage of raw materials.

Moreover, core and inter-related problems faced by manufacturing enterprises are not taken into account in many studies. More importantly, studies were not exclusively conducted in urban towns as the case of Atsibi, Adigrat, Freweyni, Kilte Awulalo, and Wukro. Therefore, the study conducted to assess factors and fertile grounds affecting the development of small and micro manufacturing enterprises in the study area. To address the overall objective of the study, the following major questions were developed and answered;

- What are the major internal and external challenges of MSMEs?

- What are the existing major opportunities that motivate MSMEs?

\section{Objectives of the Study}

The study has both general and specific objective:

\subsection{General Objective}

The overall purpose of this study is to generate adequate, upto-date and reliable information on challenges and opportunities of Micro and Small Manufacturing Enterprises in Atsibi, Adigrat, Freweyni, Kilte Awulalo, and Wukro.

\subsection{Specific Objectives}

The specific objectives of the study are:

1) To see the demography of MSMEs owners

2) To assess the major challenges and constraints facing the MSMEs

3) To assess the major opportunities for MSMEs

4) To forward possible recommendation

\section{Literature Review}

Interest in the role of small and medium-sized enterprises (SMEs) in the development process continues to be in the forefront of policy debates in developing countries. The role of finance, management skills, macro-environment factors and infrastructure have been viewed as a critical element for the performance of small and medium-sized enterprises (Anne Ngima Kinyua, 2014).

According to Annie Tan, et.,al (2012), every company faces its own set of internal and external constraints as well as special environmental incidents that effect in distinctive levels of environmental uncertainties, there is no one optimal organization design for every company because every company has different organizational culture and different perspective towards risk.

Even though entrepreneurship has its own advantages, it is not free of problems. According to Samiti (2006), classified the basic factors that affect entrepreneurs in to two broad categories -economic and social. Moreover, Gemechis (2007) supported and revealed that social and cultural attitude towards youth entrepreneurship; entrepreneurship education; administrative and regulatory framework; and business assistance and support; barriers to access technology are crucial factors that affect entrepreneurial success. There are also studies indicating the effect of human resources capabilities on the growth of SME's performance. Lee (2001), argued that human resource capacities is one of the most significant areas for the success of SMEs. Firms with a skilled and well-educated workforce are probably to be more efficient (Hewitt and Wield (1992).

There are several studies that focuses on the marketing aspects of SMEs on the performance. Marketing skills has been considered as one of the most effective factor to firm survival and growth. According to Van Scheers (2012) the lack of marketing skills has a negative impact on the success of small businesses. Pandya, V. (2012) noted that marketing limitations of an SME resemble other limited resources such as financial and human resources.

Drucker (1985) noted that new technologies improve efficiency, enable greater production, and are a source of profit for SMEs. According to Morse et al. (2007), technological capabilities benefit SMEs in several ways: they enhance SME efficiency, reduce costs, and broaden market share, both locally and globally. As noted by Lee(2001), a small business that adopts greater levels of technological sophistication can be expected to grow more rapidly than a similar firm that does not. Romijn (2001), and Yusuf et al. (2003) point out that low technological capabilities hinder and discourage SMEs from fully reaching 


\section{International Journal of Science and Research (IJSR) \\ ISSN (Online): 2319-7064}

Index Copernicus Value (2013): 6.14 | Impact Factor (2015): 6.391

their potential. As noted by Wendel Clark (2012), countries with high levels of technological growth tend to have high levels of entrepreneurial growth.

\section{Research Methodology}

\subsection{Site Selection and Description}

This descriptive study is concerned with finding out factors influencing the performance of MSEs in eastern zone of Tigray Region. Tigray is the Northernmost of Ethiopia federal states located at $12^{0} 15-4^{0} 57$ longitude and $36^{\circ} 27$ $39^{0} 59$ latitude. The State of Tigray shares common borders with Eritrea in the north, the State of Afar in the east, the State of Amhara in the south, and the Republic of the Sudan in the west. Excluding Mekelle town, the state capital, there are five administrative zones, namely Eastern, Northern, Central, Western and North Western. of course, the aforementioned zones further divided into some administrative units including the selected study area eastern zone that divided into nine district (Irob, Gulemekeda, Adigrat, Ganta-Afeshum, Hewzen, Saesi tsaed-emba, Atsibi Wukro kiltie-awalo, and Wukro). Consequently this study has conducted in five selected five towns ( Atsibi, Adigrat, Freweyni, Kilte Awulalo, and Wukro) of eastern zone (http://www.Tigrayonline.com/Tigraystate.html).

\subsection{Research Design}

This study is both qualitative and quantitative research that attempts to accumulate existing information and data regarding challenges and opportunities of Small Scale Manufacturing enterprises. It is appropriate to use this method in order to verify the observations regarding the intended research questions. The research utilized both descriptive and exploratory research methods. Existing literatures were also used in order to verify the observations and come up with preliminary ideas regarding the research domain.

\subsection{Data Collection}

The study employed both primary and secondary sources of data collection.

\subsubsection{Primary Sources}

In order to realize the target, the study has used welldesigned structured questionnaire. The required data has been collected from the owner managers/or operators of the enterprises. The layout of the questionnaire has been kept very simple to encourage meaningful participation by the respondents. The questionnaire mainly contains multiple choice questions using likert scale.

Besides, face-to-face interviews have also been conducted with the MSMEs operators/and the relevant owner managers who heads the enterprises in the selected sectors. The interview method of data collection is preferred due to its high response rate. Through interviews, clarification of issues have been achieved which has led to accuracy of data from the respondents.

\subsubsection{Secondary Sources}

The relevant secondary data has been collected from files, pamphlets, office manuals, circulars and policy papers from the MSMEs district offices. It helps the researchers to provide additional information where appropriate. Besides, variety of published book and government documents, websites, reports and newsletters have been reviewed to make the study fruitful.

\subsection{Sampling Strategy and Procedures}

The 5 district towns are purposely chosen among the remaining, as a study area for this research (Atsibi, Adigrat, Kilte Awulalo, Freweyni and Wukro). This is because it is claimed by the government of Ethiopia, that the MSMEs sector is a prime strategy to economic development in urban areas.

\subsection{Sampling Technique}

Stratified random sampling has been used to get information from different sizes of the MSMEs. This technique is preferred because it is used to assist in minimizing bias when dealing with the population. With this technique, the sampling frame can be organized into relatively homogeneous groups before selecting elements for the sample. According to Janet (2006:94), this step increases the probability that the final sample will be representative in terms of the stratified groups.

In this study to select sample size, a list of the population formally registered MSMEs until May 2015 by the Urban Development, Trade and Industry offices of the selected district towns. The total population of the study was 1682 enterprises. The researcher has used the sample size determination formula, which is developed by Yamane (1967:886), to determine the sample size of MSMEs for the study.

$$
\mathrm{n}=\mathrm{N} /\left(1+\mathrm{N}(\mathrm{e})^{2}\right)
$$

Where $\mathrm{n}$ is the sample size, $\mathrm{N}$ is the total MSMEs in the selected region. The unit of analysis of the study is the individual i.e owner of the enterprise. The investigator decided the confidence level of the study to be at $95 \%$ consequently the level of precision (e) is \pm 5 . Accordingly, 323 respondents have been selected from the total of 1820 MSMEs.

Table 2: Sample Size Allocation to the District Towns

\begin{tabular}{|c|c|c|c|c|}
\hline Towns & $\begin{array}{c}\text { Total } \\
\text { MSEs* }\end{array}$ & $\begin{array}{c}\text { MSMEs } \\
\text { Manufacturing)* }\end{array}$ & $\begin{array}{c}\text { Sample } \\
\text { respondents** }\end{array}$ & $\begin{array}{c}\text { Data } \\
\text { Collected } \\
\text { from** }\end{array}$ \\
\hline Atsebi & 2097 & 260 & 49 & 44 \\
\hline Kilte Awulalo & 1346 & 97 & 18 & 16 \\
\hline Freweyni & 2856 & 218 & 42 & 37 \\
\hline Wukro & 4856 & 479 & 92 & 89 \\
\hline Adigrat & 8563 & 628 & 121 & 118 \\
\hline Total & $\mathbf{1 9 , 7 1 8}$ & $\mathbf{1 , 6 8 2}$ & $\mathbf{3 2 3}$ & $\mathbf{3 0 3}$ \\
\hline
\end{tabular}

Source: Eastern zone administrative office annual report $(2014 / 15) *$

Computed from ** 


\section{International Journal of Science and Research (IJSR) \\ ISSN (Online): 2319-7064}

Index Copernicus Value (2013): 6.14 | Impact Factor (2015): 6.391

The interviews have also been administered on the samples. Proportionate sampling techniques have been employed to determine sample respondents from each selected towns of the study area. Moreover, having lists of MSMEs from the Micro and Small Enterprises development Agency of the selected district towns, as a sampling frame, the selection has been made randomly.

\subsection{Data Processing and Analysis}

The collected data has been quantified and edited thoroughly. Few respondents' responses have been omitted due to missing of data. Later the data was coded and computed. The competed data have been tabled to the requirements. The influence of the variables designed for each factor has been quantified with Likert scale ranging from 1 to 5. Statistical tools such as mean, standard deviations and skewness have been used to analyze and interpret the data. For calculating statistics SPSS software has been used.

\section{Results and Discussions}

Table 3: Respondents' Educational level vs Experience in the enterprise

\begin{tabular}{|c|c|c|c|c|c|c|}
\hline \multirow{2}{*}{$\begin{array}{c}\text { Educational } \\
\text { level }\end{array}$} & \multicolumn{7}{|c|}{ Experience } \\
\cline { 2 - 8 } & $=>2$ & $(2-4]$ & $(4-6]$ & $(6-8]$ & $(8-10]$ & $(10-13]$ \\
\hline Illiterate & 3 & 0 & 0 & 0 & 0 & 0 \\
\hline $1-6$ & 6 & 18 & 3 & 6 & 9 & 3 \\
\hline $7-10$ & 41 & 39 & 41 & 19 & 60 & 9 \\
\hline $11-12$ & 6 & 33 & 16 & 18 & 34 & 0 \\
\hline Certificate & 3 & 6 & 0 & 0 & 0 & 0 \\
\hline Diploma & 0 & 12 & 0 & 0 & 0 & 3 \\
\hline First Degree & 3 & 6 & 0 & 0 & 0 & 0 \\
\hline
\end{tabular}

Source: Own survey 2016

The survey results shows that majority of the entrepreneurs have obtained education between 7 to 10 grade. Next to that many of them have obtained 11-12 grades. Still now 3 entrepreneurs are illiterate. The table depicts the fact that there are no entrepreneurs have obtained degree. It shows entrepreneurship education must be strengthened at university level to focus to strengthen MSMEs. It is found by many researchers that education has its' impact on the entrepreneurial performance. Senthilkumar.K, (2015) found the correlation between entrepreneurial performance and education have positively correlated. The highest category of the entrepreneurs is at 7-10 grade with 8-10 years experience (40 numbers), This shows that those who are at middle school level were induced to become entrepreneurs whereas those who studied higher secondary or the above level have not been motivated to become entrepreneurs which is the need of the day. This is interesting to look into the fact in recent years the trend has been changed. The contribution to entrepreneurship form higher level of education have been steadily increasing sine above 11 grade there are 70 numbers of entrepreneurs with less than two years experience. The statistics shows they have initialed their business in recent time.

Table 4: Respondents' Age vs Education Level

\begin{tabular}{|c|c|c|c|c|c|}
\hline $\begin{array}{c}\text { Age in } \\
\text { Years }\end{array}$ & $\begin{array}{c}\text { Upto 6 } \\
\text { Grade }\end{array}$ & $\begin{array}{c}7 \text { to } 10 \\
\text { Grade }\end{array}$ & $\begin{array}{c}11-12 \\
\text { Grade }\end{array}$ & $\begin{array}{c}\text { Above 12 } \\
\text { Grade }\end{array}$ & Total \\
\hline Up to 29 & 6 & 42 & 16 & 15 & 79 \\
\hline $30-34$ & 9 & 68 & 34 & 15 & 126 \\
\hline $35-40$ & 12 & 27 & 15 & 3 & 57 \\
\hline $41-45$ & 6 & 3 & 14 & 0 & 23 \\
\hline $46-49$ & 0 & 12 & 0 & 0 & 12 \\
\hline Above 50 & 3 & 0 & 0 & 0 & 3 \\
\hline
\end{tabular}

\section{Source: Own survey 2016}

The results of comparison of age and educations show interesting facts. Among the entrepreneurs who are at the age between 30- 34, many of them (68 in numbers) have obtained 7 to 10 grade. The results shows at least little level of education is important to become entrepreneurs since the contribution from the grade lower than 7 grade is 34 that to relatively less in the recent years ( only 6 numbers have the age upto 29) Majority of the entrepreneurs are at middle age between 30 to 45 years old (206 out of 303 respondents). This implies that younger have not come forward to start up business. The entrepreneurs below 30 years old are relatively very less with 79 numbers. Still after 12 grades 15 young entrepreneurs are there in that 79 sampling frame, shows that in recent years the trend has changed with younger generation and they have come forward to take up the businesses.

Table 5: Business Characteristics

\begin{tabular}{|c|c|c|c|c|c|}
\hline Description & Mean & Standard Deviation & Variance & Skewness & Std.Error \\
\hline Annual sales in ETB & 164615.84 & 113725.20 & 12933421735 & 1.07 & 0.14 \\
\hline Annual expenses in ETB & 11283.87 & 8298.67 & 68867951 & 1.12 & 0.14 \\
\hline Total Capital in ETB & 118120.69 & 17999.19 & 323964001 & 1.75 & 0.14 \\
\hline Profit Percentage (ROC) & 46.72 & 42.88 & 1838.69 & 7.29 & 0.14 \\
\hline No of employees & 3.74 & 0.81 & 0.65 & -0.40 & 0.14 \\
\hline Age of business & 4.85 & 2.72 & 7.42 & 0.88 & 0.14 \\
\hline
\end{tabular}

\section{Source: Own Survey 2016}

The MSMES are operating at considerable profits with an average of 46.72 percentages of returns on the total capital employed. The study found that though there is considerable profit, it is highly varying among the enterprises which can be inferred from the high amount of standard deviation. 42.88. On seeing the standard deviation of the capital, it has less value $(17,999$ ETB) when comparing with that of the total average capital 118120 ETB which indicates that the capital employed for the business are not very much varying. The skeness 1.75 of the total capital employed when comparing with the skewness of ROC 7.29 confirms the the high degree of variability in the profits obtained by the enterprises. Interestingly though the variability in the investments is less the variability in the profit obtained by 


\section{International Journal of Science and Research (IJSR) \\ ISSN (Online): 2319-7064}

Index Copernicus Value (2013): 6.14 | Impact Factor (2015): 6.391

the enterprises are high. This implies that the performance of the enterprises is influenced by many factors which should be researched to reveal the same. The high amount of deviation 8298 ETB of the expenses with that of the mean 11283 ETB indicates that the variability in the operations and the variability in the quality of the materials input for the businesses or it may be due to the variability in the salary level of the employees among the enterprises. Thus the figures shown in table clearly indicate the high degree of variability both in the expenses and in the profits which also justify the aim and need of this study.

Table 5: Political and Infrastructural Factors

\begin{tabular}{|c|c|c|c|c|c|}
\hline Political Factors & \multicolumn{2}{|c|}{ Mean } & $\begin{array}{c}\text { Std. } \\
\text { Deviation }\end{array}$ & \multicolumn{2}{c|}{ Skewness } \\
\cline { 2 - 6 } & Statistic & $\begin{array}{c}\text { Std. } \\
\text { Error }\end{array}$ & Statistic & Statistic & $\begin{array}{c}\text { Std. } \\
\text { Error }\end{array}$ \\
\hline Registration & 3.9406 & .05216 & .90790 & -.203 & .140 \\
\hline Govt. Support & $3.3399 *$ & .05629 & .97991 & -.002 & .140 \\
\hline Political intervention & 3.6832 & .05683 & .98932 & -.012 & .140 \\
\hline $\begin{array}{c}\text { Information } \\
\text { accessibility }\end{array}$ & $2.9241 *$ & .06455 & 1.12358 & .066 & .140 \\
\hline PLI & 69.4092 & .64203 & 11.17579 & -.236 & .140 \\
\hline \multicolumn{7}{|c|}{ Infrastructural Factors } \\
\hline Power interruptions & $2.3993 *$ & .04517 & .78622 & 1.756 & .140 \\
\hline Water supply & 4.6060 & .05511 & .95776 & -2.635 & .140 \\
\hline $\begin{array}{c}\text { Transport } \\
\text { availability }\end{array}$ & $3.0297 *$ & $.09676 *$ & 1.68430 & -.131 & .140 \\
\hline $\begin{array}{c}\text { Business } \\
\text { development } \\
\text { services }\end{array}$ & $2.6436 *$ & .06001 & 1.04455 & .088 & .140 \\
\hline Sewerage system & 3.1632 & .08430 & 1.43054 & -.390 & .144 \\
\hline Road Facility & $4.3630 * *$ & .06096 & 1.06115 & -1.637 & .140 \\
\hline IFI & 66.7921 & .75654 & 13.16904 & -.185 & .140 \\
\hline
\end{tabular}

\section{Source: Own Survey 2016}

The table 5 indicates the political and infrastructural factors influences the performance of MSMEs. The influences are measured in likert scale and the measurements range from 1 to5. The high scores indicate the positive environment and the low score indicates the negative environment in the businesses towards the performance. The results shows that there is a need for improving information accessibility regarding registration process since the score is very less 2.6 out of 5. Government support must have to be improved since the mean score 3.33 is considerably low. While considering the infrastructural factors the road facilities are very good which are highly supporting the performance of the MSMEs which can be inferred from the high mean score 4.36. Though the road facility is good the transport availability is not good i.e there is less transport availability which can be inferred from the low score 2.93. Yet the highest std. deviation 1.6 shows that in some places the transport availability is good whereas in the rest it is not so. Power interruptions are more which impinges the performance which is deduced from the lowest mean score 2.39. There is a need for business development services which is inferred from the low mean score 2.64. It is interest to not that the research conducted by Mbugua Stephen Kamunge, Dr. Agnes Njeru and, Ondabu Ibrahim Tirimba (2014) which infdicates the high affect of political and legal factors on the performance of Small and Micro Enterprises in Limuru Town Market of Kiambu County, Kenya.
Table 6: Financial factors

\begin{tabular}{|c|c|c|c|c|c|}
\hline \multirow{2}{*}{ Factors } & \multicolumn{2}{|c|}{ Mean } & $\begin{array}{c}\text { Std. } \\
\text { Deviation }\end{array}$ & \multicolumn{2}{c|}{ Skewness } \\
\cline { 2 - 6 } & Statistic & $\begin{array}{c}\text { Std. } \\
\text { Error }\end{array}$ & Statistic & Statistic & $\begin{array}{c}\text { Std. } \\
\text { Error }\end{array}$ \\
\hline $\begin{array}{c}\text { Financial } \\
\text { statements }\end{array}$ & $2.0792 *$ & .06743 & 1.17380 & .896 & .140 \\
\hline Cash management & 3.3399 & .06966 & 1.21250 & -.194 & .140 \\
\hline Skills in WC mgmt $4.0099 *$ & .05904 & 1.02771 & -.665 & .140 \\
\hline Credit management & 3.9472 & .06300 & 1.09659 & -.835 & .140 \\
\hline $\begin{array}{c}\text { Debtors } \\
\text { management }\end{array}$ & 3.9802 & .06254 & 1.08859 & -1.061 & .140 \\
\hline Bad debt mgmt & $4.2970 * *$ & .06283 & 1.09373 & -1.574 & .140 \\
\hline Credit institutions & 3.6007 & .06987 & 1.21617 & -.531 & .140 \\
\hline $\begin{array}{c}\text { Collateral } \\
\text { requirements }\end{array}$ & $1.5215 *$ & .04877 & .84886 & -1.948 & .140 \\
\hline $\begin{array}{c}\text { Interest rate on } \\
\text { loans }\end{array}$ & 4.3960 & .05396 & .93934 & -1.566 & .140 \\
\hline Loan procedures & 4.5380 & .05135 & .89390 & -2.089 & .140 \\
\hline $\begin{array}{c}\text { Owner's } \\
\text { intervention }\end{array}$ & 3.0231 & .08076 & $1.40580 *$ & -.106 & .140 \\
\hline $\begin{array}{c}\text { Accounting } \\
\text { Computer } \\
\text { application }\end{array}$ & $1.8317 *$ & .05555 & $.96703 *$ & 1.161 & .140 \\
\hline Source: Own Sur & .03531 & .61457 & 2.034 & .140 \\
\hline
\end{tabular}

\section{Source: Own Survey 2016}

The results depict that the collateral requirements by the credit institutions are more and are adversely affect the MSMES. The results are in consonance with Shah et al.(2013) who found that financial institutions behave more cautiously when providing loans to SMEs, and SMEs are usually charged comparatively high interest, high collateral and loan guarantees which discourage firms from obtaining loans from banks. The results depict that the MSMEs have to be modernised since the mean score of computer applications is the lowest with 1.3 out of 5 . However the highest skewness shows few enterprises are using computers for their operations. In accounting practises and preparing financial statements the enterprises are lagging which is inferred by the low mean scores 1.8 and 2.08 respectively. However the enterprises are good in managing bad debts which is clear from the higher mean score 4.29. The enterprises are viable to manage its day to day operations with adequate working capital which is inferred from the high mean score 4.09. But there is an inadequacy in number of credit institutions which is inferred from the moderate score 3.6. Cash is not well managed (relatively low score 3.3). Withdraws are made by the owners without consideration of net income generated which interrupts the day to day operations of the MSMEs which is realized the score 3.02. However there is a high standard devaiation of 1.4 which implies that the owners' intervention is not in all the enterprises. 


\section{International Journal of Science and Research (IJSR) \\ ISSN (Online): 2319-7064}

Index Copernicus Value (2013): 6.14 | Impact Factor (2015): 6.391

Table 7: Marketing factors

\begin{tabular}{|c|c|c|c|c|c|}
\hline \multirow{2}{*}{ Factors } & \multicolumn{2}{|c|}{ Mean } & $\begin{array}{c}\text { Std. } \\
\text { Deviation }\end{array}$ & \multicolumn{2}{c|}{ Skewness } \\
\cline { 2 - 6 } & Statistic & $\begin{array}{c}\text { Std. } \\
\text { Error }\end{array}$ & Statistic & Statistic & $\begin{array}{c}\text { Std. } \\
\text { Error }\end{array}$ \\
\hline Sales forecast & 3.7921 & .06095 & 1.06090 & -.514 & .140 \\
\hline Product design & 4.3069 & .05294 & .92152 & -1.133 & .140 \\
\hline Market information & 3.5974 & .06013 & 1.04672 & -.025 & .140 \\
\hline $\begin{array}{c}\text { Customer } \\
\text { relationship }\end{array}$ & $4.1485^{*} *$ & .05475 & .95307 & -.763 & .140 \\
\hline Market availability & 3.5776 & .05226 & .90971 & .087 & .140 \\
\hline Market expansion & 3.5927 & .05734 & .99651 & -.045 & .140 \\
\hline Promotions & 3.3444 & .06484 & 1.12682 & -.596 & .140 \\
\hline Competitiveness & 3.2706 & .05076 & .88364 & .515 & .140 \\
\hline Price of the product & $2.3003^{*}$ & .06424 & $1.3218 *$ & .945 & .140 \\
\hline Product features & $2.5050^{*}$ & .07932 & 1.3804 & .628 & .140 \\
\hline $\begin{array}{c}\text { Distribution } \\
\text { Marting Index }\end{array}$ & $1.7162 *$ & .05684 & .98933 & 1.255 & .140 \\
\hline $\begin{array}{c}\text { Marketing } \\
\text { Score }\end{array}$ & 66.0102 & .52022 & 9.04040 & -.273 & .140 \\
\hline Source: Own Survey 2016 & & & & \\
\hline
\end{tabular}

\section{Source: Own Survey 2016}

The enterprises are relatively not good in marketing their products since all the mean scores for the factors are less than 4 except customer relationship. This implies that the enterprises are good in maintaining the relationship with customers. However overall their marketing efforts are not appreciable which can be inferred from the moderate scores in the table. The prises of the products are varying which is inferred from the low mean score 2.3. It is also confirmed with the highest standard deviation that the prices of the products are highly varying/ i.e there is no uniform pricing among the enterprises. It may lead to competition and losing customers because of price variations. The products are also customised with various features which inferred from the low score 2.5. Results shows that the products are not cusmised or the marketing efforts are not customer centric. The enterprises are also very weak on managing their distributions. The enterprises also found difficulties in distributing their products. The availability of the products produced by the enterprises are not well displayed and distributed. it is inferred from the lowest mean score 1.71 . This shows that the enterprises do not have proper distributors or supply effectiveness with proper distribution and display of their products. However their promotional and market expansion efforts are moderate with score ranging from 3 to 4 . Van Scheers (2012) the lack of marketing skills has a negative impact on the success of small businesses. It is inline with the research results that with the high mean score 3.27 of competitiveness.

Table 8: Operational factors

\begin{tabular}{|c|c|c|c|c|c|}
\hline \multirow{2}{*}{ Factors } & \multicolumn{2}{|c|}{ Mean } & $\begin{array}{c}\text { Std. } \\
\text { Deviation }\end{array}$ & \multicolumn{2}{c|}{ Skewness } \\
\cline { 2 - 6 } & Statistic & $\begin{array}{c}\text { Std. } \\
\text { Error }\end{array}$ & Statistic & Statistic & $\begin{array}{c}\text { Std. } \\
\text { Error }\end{array}$ \\
\hline Production planning & 3.9868 & .05142 & .89507 & -.337 & .140 \\
\hline Production delay & $3.0528 *$ & .06638 & 1.15540 & -.091 & .140 \\
\hline Production standards & 4.1716 & .04757 & .82806 & -.717 & .140 \\
\hline $\begin{array}{c}\text { Machinery } \\
\text { utilization }\end{array}$ & $4.3828 * *$ & .05009 & .87191 & -1.462 & .140 \\
\hline Employee utilization $4.4686 * *$ & .04354 & .75786 & -1.341 & .140 \\
\hline Time utilization & 4.1782 & .04749 & .82666 & -.484 & .140 \\
\hline Technology & $2.9802 *$ & .05968 & 1.03879 & -.032 & .140 \\
\hline $\begin{array}{c}\text { Adequacy of } \\
\text { machineries }\end{array}$ & $2.3861 *$ & .08150 & $1.41868 *$ & .590 & .140 \\
\hline
\end{tabular}

\begin{tabular}{|c|c|c|c|c|c|}
\hline Operational skills & 3.9472 & .05961 & 1.03763 & -.538 & .140 \\
\hline Material Handling & $4.1287 * *$ & .05610 & .97651 & -.862 & .140 \\
\hline Layout & 3.9934 & .05532 & .96286 & -.435 & .140 \\
\hline Maintenance & $4.2013 * *$ & .05338 & .92914 & -1.159 & .140 \\
\hline No Breakdowns & 4.0693 & .06915 & 1.20367 & -1.269 & .140 \\
\hline $\begin{array}{c}\text { Inventory } \\
\text { management }\end{array}$ & 4.0297 & .05827 & 1.01436 & -.673 & .140 \\
\hline Supply management & 4.1650 & .05627 & .97951 & -1.060 & .140 \\
\hline $\begin{array}{c}\text { Plant rent cost } \\
\text { Operational Index } \\
\text { Score }\end{array}$ & $2.5281 *$ & .07194 & 1.25217 & .094 & .140 \\
\hline Source: Orn Sure & 76.0561 & .72736 & 12.66115 & -.444 & .140 \\
\hline
\end{tabular}

\section{Source: Own Survey 2016}

The enterprises are operating well with effective planning ( mean score 3.98). The scores regarding plant utilisation depict that the enterprises plant utilisation ie utilising the machineries employees etc are appreciable. The highest mean score 4.66 implies that the employees are effectively utilised and managed. Te enterprises are good in material handling and maintenance with the mean scores 4.1 and 4.2 respectively. They use all the machineries effectively (mean score 4.38). The above results clearly indicate the operations are well managed with respect to utilisation of the resources. Though resources are managed well, they do not have adequate machineries and updated technology which can be inferred from the low mean scores 2.38 and 2.98 respectively. The highest std. Deviation 1.4 for adequacy of machineries indicates that some of the enterprises have been equipped with all necessary equipments and the rest do not have. i.e there is a high amount of variability in the availability of machineries in the enterprises. The results are inconsonce with the researchers conducted by by Romijn (2001), and Yusuf et al. (2003) who found that low technological capabilities hinder and discourage SMEs from fully reaching their potential. It is also observed that the rent and cost towards the plant is high the enterprise are impinged with the expenses since the mean score 2.52 is very low

Table 9: Entrepreneurs Attributes

\begin{tabular}{|c|c|c|c|c|c|}
\hline \multirow{2}{*}{ Factors } & \multicolumn{2}{|c|}{ Mean } & $\begin{array}{c}\text { Std. } \\
\text { Deviation }\end{array}$ & \multicolumn{2}{c|}{ Skewness } \\
\cline { 2 - 6 } & Statistic & Std. Error & Statistic & Statistic & $\begin{array}{c}\text { Std. } \\
\text { Error }\end{array}$ \\
\hline Skills & 3.9439 & .04361 & .75915 & -.226 & .140 \\
\hline Experience & $4.2442 * *$ & .04360 & .75889 & -.624 & .140 \\
\hline Social networks & $4.3333 * *$ & .04402 & .76629 & -.826 & .140 \\
\hline Family & $4.3300^{* *}$ & .05716 & .99502 & -1.553 & .140 \\
\hline Friends & 3.7063 & .06245 & 1.08704 & -.485 & .140 \\
\hline Motivation and drive & $4.5331 * *$ & .04132 & .71799 & -1.364 & .140 \\
\hline Tolerance & $4.4521 * *$ & .03981 & .69305 & -1.059 & .140 \\
\hline $\begin{array}{c}\text { Persistence and } \\
\text { courage }\end{array}$ & $4.3366 * *$ & .03676 & .63991 & -.438 & .140 \\
\hline $\begin{array}{c}\text { Commitment and } \\
\text { responsibility }\end{array}$ & $4.4620^{* *}$ & .03845 & .66937 & -.861 & .140 \\
\hline $\begin{array}{c}\text { Administrative } \\
\text { ability and leadership }\end{array}$ & 3.7492 & .04061 & .70696 & -.110 & .140 \\
\hline $\begin{array}{c}\text { Entrepreneurs' } \\
\text { training }\end{array}$ & $2.6040^{*}$ & .06294 & $1.09556 *$ & .090 & .140 \\
\hline Information & 4.0495 & .05554 & .96676 & -.586 & .140 \\
\hline Business plan & $2.8746 *$ & .05343 & .93006 & -.643 & .140 \\
\hline $\begin{array}{c}\text { Entrepreneurial } \\
\text { Attribute Index }\end{array}$ & 77.1617 & .48275 & 8.40314 & -.328 & .140 \\
\hline
\end{tabular}

Source: Own Survey 2016

\section{Volume 5 Issue 6, June 2016 www.ijsr.net}




\section{International Journal of Science and Research (IJSR) \\ ISSN (Online): 2319-7064}

Index Copernicus Value (2013): 6.14 | Impact Factor (2015): 6.391

The entrepreneurs' attributes towards the business is very good which observed from the mean scores which are all more than 2.5.Though their education and knowledge level is moderate with the scores 3.05 and 3.2, they have good social networks (mean score 4.433) good family support (mean score 4.33)and experience (mean score 4.2). Their attitude toward business is at appreciable level which is observed by the attributes motivation and drive, tolerance, persistence and commitment with the mean scores 4.53, $4.45,4.33$ and 4.46 respectively. They are lagging in undergoing training to strengthen their business which can be inferred from the low score 2.6. The results implies that they need to improve themselves in planning the business since the score 2.87 for the business plan is also low. While looking the overall perspectives their attitude is appreciable which drives the business. Yet they need to improve themselves by attending training and they need to be trained in formal business plan which may lead the enterprises to better performance. The results reflects the results of the study conducted by Brush, C.G, And Hisrich, R.D. (2000) on Israeli women entrepreneurs. They found entrepreneurial socialization is an effective on performance. The results in line with the research conducted by Woldie, A., P. Leighton and A. Adesua. (2008) who found the influence of entrepreneurs' characteristics on performance is highly effective.

\section{Conclusion}

The study has been conducted to explore the challenges and opportunities exited for the MSMEs in eastern Tigray Region of Ethiopia. It has found that there are more challenges in micro level related to production operations, marketing and financial operations of the MSMEs. It has found that there are seldom young entrepreneurs. Their education level is moderate with high school level. The enterprises face difficulties in getting loans from the financial institutions due to high collateral requirements. The plant has suffered from inadequacy of machineries and lack of modern technology. However employees are effective in managing the situations. The plants are also impinged by frequent power interruptions and inadequate transport facility. The entrepreneurs have good attitude towards the business. Yet they have to upgrade and develop themselves by attending training and development programs conducted by various sources which will be the source of development of the enterprises. The enterprises do not concentrate on growth perspectives since they are very weak in distributing their products. However the enterprises have good relationship with customers.. Hence there is a scope for developing and expanding their business. The entrepreneurs hence should focus on strengthening their distribution which will ensure the sustainable growth of the enterprises.

\section{Suggestion}

The study throws light on challenges of MSMEs. It is observed that many of the challenges are at micro level and controllable that could be improved. The concentration and strategies on distribution management have to be also improved to expand and strengthen the business. The entrepreneurs should also develop their knowledge profile on business venture through taking/attending trainings, conferences and other sources. The entrepreneurs should focus on upgrading the technologies used in the enterprises with modern machineries to compete and sustain in the current global scenario. The financial institution may ease the loan process and collateral requirements. Moreover, as long as this sector is expected to contribute more to the growth and transformation plan (GTP 2) of the region and the country, then the government should give priority in distributing electricity by clustering very important MSMEs in one particular place. Besides, the enterprise owners should try to seek other alternative source of power other than entirely depending electricity offered by the government such as electric generator.

\section{References}

[1] Anne Ngima Kinyua (2014), Factors Affecting the Performance of Small and Medium Enterprises in the Jua Kali Sector In Nakuru Town, Kenya

[2] Annie Tan, et., al (2012),A Study on Factors Affecting the Performance of SMEs in Malaysia

[3] Asma Benzazoua Bouazza et.,al (2015), Establishing the Factors Affecting the Growth of Small and Medium-sized Enterprises in Algeria.

[4] Central Statistics Agency (CSA) (2007), Statistical Abstract, Federal Democratic Republic of Ethiopia.

[5] Gemechis Tefera .(2007) Attitude Of College Students Towards Entrepreneurship: A Case Study of Addis Ababa University and Rift Valley University College.

[6] Hisrich, R.D. (2005), Entrepreneurship.7th Edition, Boston: McGraw Hill.

[7] Konjit D. (2010), Women In The Development Of Micro \& Small Enterprises To

[8] Ensure Sustainable Development \& Food Security

[9] Mekonnen Drbei and Tilaye Kassahun (2013), Deterrents to the Success of Micro and Small Enterprises in Akaki-Kality Sub-City

[10] Samiti, V. (2006), A research study on Entrepreneurial Challenges for SC Persons in India.New Delhi: Planning Commission Government of India.

[11] http://www.Tigrayonline.com/Tigraystate.html

[12] Woldie, A., P. Leighton and A. Adesua. (2008), "Factors Influencing Small and Medium Enterprises (SMEs): an exploratory study of owner/manager and firm characteristics", Banks and Bank Systems, Vol 3, issue 3 .

[13] Brush, C.G, And Hisrich, R.D. (2000) Women-Owned Business: An exploratory study comparing factors affecting performance. Available at www.riseb.org?finalbrysh.Pdf. Retrieved October, 2015.

[14] Mbugua Stephen Kamunge, Dr. Agnes Njeru and , Ondabu Ibrahim Tirimba (2014)n Factors Affecting the Performance of Small and Micro Enterprises in Limuru Town Market of Kiambu County, Kenya,

[15] Van Scheers, L. (2011). SMEs' marketing skills challenges in South Africa. African Journal of Business Management, 5(13), 5048-5056.

[16] Senthilkumar K. (2015), The influence of social factors on the knowledge of Sago entrepreneurs in Salem region, International journal of applied scienee and engineering, 2015

\section{Volume 5 Issue 6, June 2016}




\section{International Journal of Science and Research (IJSR) \\ ISSN (Online): 2319-7064}

Index Copernicus Value (2013): 6.14 | Impact Factor (2015): 6.391

[17] Shah, S.F.H., Nazir, T., Zaman, K., \& Shabir, M. (2013). Factors affecting the growth of enterprises: A survey of the literature from the perspective of small $\&$ medium sized enterprises.

[18] The Ethiopian Federal Democratic Republic government Micro and Small Enterprises Development Strategy (2010).

[19] Yusuf, et al. (2003), Innovative East Asia: The Future of Growth, Washington, D. C.: The World Bank, a Copublication of the World Bank and Oxford University Press.

Volume 5 Issue 6, June 2016 www.ijsr.net 